\title{
Unipolar Depresyon ve Bipolar Duygu Durum Bozukluğunda Serum Magnezyum Düzeylerinin Değerlendirilmesi: Retrospektif Bir Çalışma
}

Bozok Üniversitesi Tip Fakültesi Ruh Sağlığı ve Hastalıkları Anabilim Dalı, Yozgat, Türkiye

Correspondence:

Gül Ferda CENGİZ

Bozok Üniversitesi Tip Fakültesi Ruh Sağlığı ve Hastalıkları Anabilim Dalı, Yozgat, Türkiye

e-mail: glferda@hotmail.com

\section{Özet}

Magnezyum sinir sisteminin ișleyișinde önemli rolü olan bir elementtir. Bu çalıșmada unipolar depresyon ve bipolar duygudurum bozukluğu tanısı olan hastalarda serum magnezyum düzeylerinin araștırılması amaçlanmıștır. Psikiyatri polikliniğine başvurusu olan hastaların kayıtları retrospektif olarak taranarak, serum magnezyum düzeyleri bakılmış olan 49 depresif bozukluk ve 21 bipolar duygu durum bozukluğu olan hasta çalıșma grubu olarak, herhangi bir psikiyatrik hastalığı bulunmayan 50 kiși ise kontrol grubu olarak toplandi. Hem unipolar depresyonu olan hastalarda hem de bipolar duygu durum bozukluğu olanlarda kontrol grubuna kıyasla daha yüksek serum magnezyum düzeyleri saptandı. Unipolar depresyon ve bipolar duygu durum bozukluğu arasında ise anlamlı farklılık saptanmadı. Unipolar depresyon ve bipolar duygu durum bozukluğunda serum magnezyum düzeylerinin yüksek bulunması, magnezyumun bu hastalıkların patofizyolojisinde önemli olabileceğini göstermekte olup, potansiyel bir biyomarker olabileceğine ișaret etmektedir.

Anahtar Kelimeler: Depresyon; bipolar bozukluk; magnezyum; duygu durum bozukluğu

\section{Abstract}

Magnesium is an element that plays an important role in the functioning of the nervous system. The aim of this study was to investigate serum magnesium levels in patients with unipolar depression and bipolar disorder. The records of the patients who applied to the psychiatry outpatient clinic were retrospectively reviewed. Forty-nine patients with depressive disorder and 21 patients with bipolar mood disorders and 50 subjects without any psychiatric disorder that serum magnesium levels were studied previously were involved in the study. Both patients with unipolar depression and bipolar mood disorder had higher serum magnesium levels than the control group. There was no significant difference between unipolar depression and bipolar disorder. High serum magnesium levels in unipolar depression and bipolar mood disorder show that magnesium may be important in the pathophysiology of these diseases, indicating that it may be a potential biomarker.

Keywords: Depression; bipolar disorder; magnesium; mood disorders 


\section{Giriş}

Elektrolitler, duygu durum bozukluklarının patofizyolojisinde yer alan monoaminlerin metabolizmasında önemli rol oynarlar (1). Magnezyum en fazla bulunan ikinci hücre içi katyon olup yüzlerce enzimin de kofaktörüdür (2). Ayrıca hücre döngüsünde, karbonhidrat, protein, yağ ve nükleik asit metabolizmasında yer alır, hücre memran geçirgenliğinden ve hücre göçünden kismen sorumlu olup, DNA, RNA ve glutatyon sentezi, ATP üretimi ve kullanımı, nöromusküler iletim, kemik mineralizasyonu, kan glukoz kontrolü ve kan basıncı düzenlenmesinde görev alır (3). Magnezyumun özellikle santral sinir sistemi için de önemli görevleri bulunmaktadır. Adrenerjik ve serotonerjik reseptörlerin normal işlevlerini gösterebilmeleri için gerekli olan tirozin ve triptofan hidroksilazın kofaktörüdür. Ek olarak 5-HT-1a serotonin reseptör transmisyonunda direkt etkisi olduğu da bildirilmiştir (4,5). Magnezyum santral sinir sisteminde N-metil D-aspartat (NMDA) reseptör kanallarını bloke eder (6). Ekstrasellüler magnezyum düşüklüğü NMDA dizinhibisyonuna bağlı olarak, santral hipereksitebiliteyi artırır (7) ve aynı zamanda magnezyum, NMDA reseptör kompleksinin alt ünitesi olan GluN2B ekspresyonunu da artırır (3). Magnezyum iyonları nöronal NMDA kanallarındaki kalsiyum iyonlarını regüle eder ve bu da nöronal nitrik oksit üretimini düzenlemeye yardımc1 olur. Düşük magnezyum konsantrasyonu olması durumunda nöron içine kalsiyum akışı artar ve patolojik miktarlarda nitrik oksit üretimi olur. Post sinaptik bölgedeki artmış nitrik oksit üretimi ise presinaptik uçlara yayılarak depresyon gibi çeşitli patolojik durumlara yol açabilir (8). Magnezyum prefrontal kortekste BDNF ekpresyonunu artırır, ek olarak hipokampal ateşlemeyi baskılar ve prefrontal kortekste protein kinaz c yolağını düzenler (9). Bütün bu fonksiyonlar depresyon patofizyolojisinde önemli mekanizmalardır. Magnezyumun antienflamatuar yanıtta ve uyku üzerinde de etkili olduğu bildirilmektedir (10).

Hipokampüsteki düşük magnezyum düzeyleri ve kalsiyum ve glutamat düzeylerindeki artışın duygu durum bozukluklarının gelişmesine yol açtığ1 düşünülmektedir (9). Üstelik rutin klinik uygulamalarda da magnezyum oldukça kolay ölçülebilmektedir (11).
Santral sinir sistemindeki önemli görevleri olması ve kandan kolaylıkla ölçülebilmesi sebebiyle de magnezyum ile psikiyatrik hastalıkların ilişkisi araştırmacıların ilgisini çeken bir konu olmuştur. Yapılan çalışmaların bir kısmında magnezyumun diyetle kısıtlı alımının depresyonla ilişkili olduğu gösterilmiştir $(12,13)$ Hatta depresyonda tedaviye magnezyum eklemenin olumlu katkısı olduğunu bildiren çalışmalar da mevcuttur $(14,15)$. Ancak hala duygu durum bozukluklarında magnezyum düzeyinde düşüş mü yoksa artış $m 1$ olduğu konusu net değildir. Bazı çalışmalar düşük magnezyum düzeyinin depresyon için potansiyel bir marker olduğunu söylerken (11) bazıları da unipolar depresyon ve bipolar duygu durum bozukluğunda magnezyum düzeyinde artış olduğunu $(16,17)$ belirtmiş̧ir. Bazıları ise kanıtların tutarsız olduğunu, daha fazla prospektif çalışmaya ihtiyaç olduğunu savunmaktadır (18).

$\mathrm{Bu}$ çalışma ile unipolar depresyon ve bipolar duygu durum bozukluğu olan hastaların serum magnezyum düzeylerinin değerlendirilmesi ve kontrol grubu ile karşılaştırılarak bu hastalıklarda magnezyum düzeyinin nasıl etkilendiğinin belirlenmesi amaçlanmıştır.

\section{Gereç ve Yöntemler}

Çalışma için önce Üniversite Tıp Fakültesi Araştırma ve Uygulama hastanesi psikiyatri bölümüne 2015 ve 2019 yılları arasında başvuran hastaların verileri retrospektif olarak tarandi. İçlerinde unipolar depresyon ve bipolar duygu durum bozukluğu tanıları olanlar ve serum magnezyum düzeyi bakılmış olan hastalar çalışma grubunu oluşturdu. Sinirlilik şikayeti ve uyum sorunları nedeniyle polikliniğimize başvurmuş, yapılan muayenesinde psikiyatrik bir hastalığının olmadığına karar verilmiş ve kan tetkikleri istenmiş hastalar taranarak kontrol grubu oluşturuldu. Çalışma grubunda unipolar depresyon tanısı almış 49 ( 32 kadın, 17 erkek) hasta ve bipolar duygu durum bozukluğu olan 21 hasta (11 kadın, 10 erkek) bulunmaktaydı. Kontrol grubunda ise 50 kişi ( 32 kadın, 18 erkek) bulunmaktaydi. Depresif veya bipolar duygu durum bozukluğuna ek olarak başka psikiyatrik hastalığı olanlar, psikoaktif madde (alkol ve madde) kullanımı olanlar ve ciddi bedensel hastalığı olanlar çalışmadan dışlandı. 
Çalışma için aynı hastanenin etik kurulundan onay alınmıştır ( etik kurul karar numarası:2017KAEK-189_2019.11.27_03).

\section{Istatistiksel analiz}

Tüm veriler SPSS (Statistical Package for the Social Sciences) versiyon 15 program ile analiz edildi. Kategorik veriler ki-kare testi kullanılarak analiz edildi ve sayı olarak ifade edildi. Sürekli veriler için ortalama ve standart sapma değerleri verildi. Unipolar depresyon, bipolar duygu durum bozukluğu ve kontrol grubu arasinda serum magnezyum düzeylerinin karşılaştırması parametrik test varsayımları karşılanmadığından Kruskal Wallis testi kullanılarak yapıldı. Anlamlılık düzeyi için $\mathrm{p}<0.05$ kabul edildi. Anlamlı farklılık saptandığ 1 durumda farkın hangi gruptan kaynaklandığını tespit etmek için ikili gruplar arasında Mann- Whitney U testi uygulandı. Bonferroni düzeltmesi yapılarak yeni anlamlılık düzeyi 0.017 olarak belirlendi.

\section{Bulgular}

Unipolar depresyon grubunun yaş ortalaması $42,10 \pm 13,76$, bipolar bozukluk grubunun
$43,57 \pm 11,27$, kontrol grubunun ise $41,64 \pm 11,05$ idi. Gruplar arasında yaş ve cinsiyet bakımından anlamlı fark yoktu( yaş için $\mathrm{p}=0,907$, cinsiyet için $p=0,745$ ). Çalışma grubunda diabetes mellitus tanısı olan 7 kişi, hipertansiyon olan 6 kişi bulunurken, kontrol grubunda diabet tanıs1 olan 3 kişi, hipertansiyon tanısı olan 5 kişi bulunmaktaydi.

Serum magnezyum düzeyleri (mg/dl) bakımından gruplar karşılaş̧ırılldığında ise gruplar arası anlamlı farklılık saptandı (tablo-1, şekil-1). Farklılığın hangi gruptan kaynaklandığını belirlemek için gruplar ikili olarak karşılaştırıldı (tablo-2).

Unipolar depresyon ve kontrol grubu karşılaştırıldığında (tablo-2); yeni p değeri olan 0,017'ye göre aralarında anlamlı fark bulundu $(\mathrm{p}=0,003)$, bipolar bozukluk ve kontrol grubu karşılaştırıldığında da yine aralarında anlamlı fark saptand $1 \quad(p=0,014)$. Ancak depresif bozukluk ve bipolar bozukluğun ikili karşılaştırması sonucu istatistiksel olarak anlamlı fark bulunmadi $(\mathrm{p}=0,788)$.

Tablo1. Hastalık grubuna göre magnezyum düzeylerinin karşılaştırılması

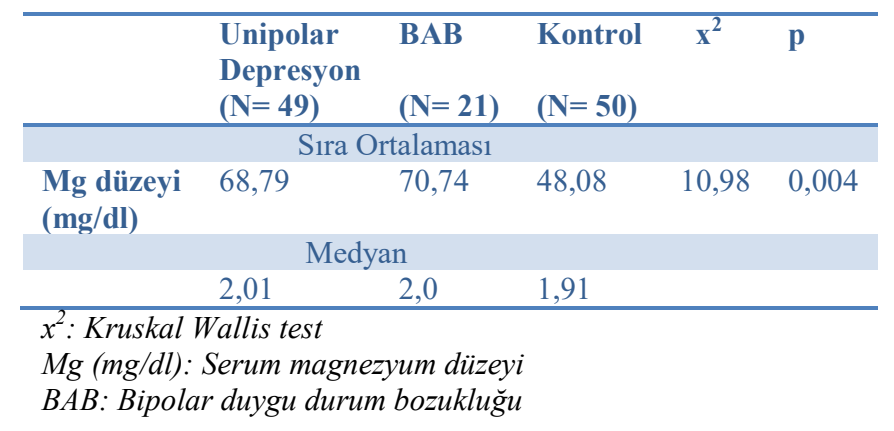

Tablo 2. Grupların magnezyum düzeyleri (mg/dl) bakımından birbiri ile karşılaştırılması

\begin{tabular}{llll}
\hline & Mean rank & $\mathbf{U}$ & $\mathbf{p}$ \\
\hline Depresyon- & 58,71 & 798,0 & $0,003^{*}$ \\
Kontrol & 41,46 & & \\
BAB- & 45,24 & 331,0 & $0,014^{*}$ \\
Kontrol & 32,12 & & \\
Depresyon- & 35,07 & 493,5 & 0,788 \\
BAB & 36,50 & & \\
\hline$*: p<0,017$ & & &
\end{tabular}




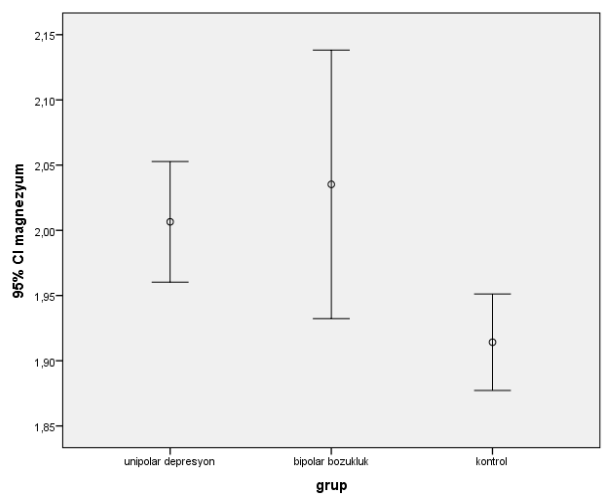

Şekil 1. Gruplar arasında serum magnezyum düzeylerinin karşılaştırılması

\section{Tartışma ve Sonuç}

$\mathrm{Bu}$ çalışmada unipolar depresyon ve bipolar duygu durum bozukluğu olan hastaların serum magnezyum düzeyleri kontrol grubuna göre anlamlı olarak daha yüksek saptanmıştır. Unipolar depresyon ve bipolar bozukluk gruplarının birbiri ile karşılaştırılması sonucunda ise iki grup arasında anlamlı fark saptanmamıştır. Literatür incelendiğinde depresyonda serum magnezyum düzeyleriyle ilgili çelişkili sonuçların yer aldığ görülmektedir. Deb ve arkadaşları 30 depresif hastayla yaptıkları çalışmada depresif bozukluğu olan grupta anlamlı olarak daha düşük serum magnezyum düzeyleri saptamışlardır (8). You ve arkadaşlarının yaptıkları metaanalizde de depresif hastalarda serum magnezyum düzeyleri kontrollerden daha düşük bulunmuştur. Ayrıca metaanalize dâhil edilen çalışmalardan iki tanesi analiz dışı bırakıldığında ise bulunan anlamlılığın kaybolduğu saptanmıştır. Bununla birlikte plazma ve serebrospinal sıvidaki magnezyum düzeyleri değerlendirildiğinde ise fark bulunmamıştır (11). Üstelik dâhil edilen çalışmaların çoğunun da eski tarihli olmasının da göz önünde bulundurulması gerektiğini söyleyen yazarlar, bu nedenlerle bulunan sonuçların dikkatli yorumlanması gerektiğini vurgulamışlardır. Başka bir çalışmada ise burada sunulan çalışmayla uyumlu olarak, ilaç kullanmayan depresif bozukluk hastalarının kan magnezyum düzeyleri sağlıklı kontrollerden daha yüksek bulunmuştur (1). Bir diğerinde ise ilaç tedavisi almayan 20 depresif bozukluk hastasıyla yapılan çalışma sonucunda mevcut çalışmayla uyumlu olarak yüksek serum magnezyum düzeyleri saptanmıştır (19).

Bugüne kadar bipolar duygu durum bozukluğunda serum magnezyum düzeyini değerlendiren fazla çalışma bulunmamakla birlikte, burada sunulan çalışma sonuçlarıyla uyumlu olarak Siwek ve arkadaşları da bipolar duygu durum bozukluğu olan hastalarda; manik, hipomanik veya depresif epizodda olmasından bağımsız olarak serum magnezyum düzeylerini sağlıklı kontrollere kıyasla daha yüksek olarak bulmuşlardır (20). Aynı zamanda magnezyum düzeyleri ile manik veya hipomanik epizod süreleri ve geçen yılki alevlenme sayısı arasında pozitif yönde anlamlı ilişki saptamışlardır. Yine mevcut çalışmayı destekler nitelikte Imada ve ark.nın 34 bipolar 37 depresif bozukluk hastasıyla yaptıkları çalışmalarında da her iki grupta kontrol grubuna kiyasla daha yüksek serum magnezyum değerleri saptanmıştır (21). Ayrıca bu çalışmada magnezyum düzeyleri ile hastalığın aktif fazı veya remisyon fazında olması arasında ilişki de saptanmamıştır. Yazarlar magnezyum düzeylerinin hastalığın fazı veya şiddetinden etkilenmemesinden dolayı serum magnezyum düzeyinin patofizyolojiyi gösteren potansiyel bir marker olabileceğini iddia etmişlerdir. Burada sunulan çalışmada ise retrospektif olarak tasarlanmış olması sebebiyle hastalık şiddeti ve fazına dair mevcut bilgi olmadığından böyle bir değerlendirme yapılamamıştır. Yüksek magnezyum düzeyinin vücudun patofizyolojiyle 
karşılaşmasına verdiği bir savunma tepkisi olabileceği düşünülmektedir. Şöyle ki magnezyumun antidepresan etkinliği olduğu, vücutta azalmasının nöronlarda NMDA blokajını engellediği ve hipereksitabiliteyi artırdığı bilinmektedir $(7,22)$. Belki de organizmanın magnezyum düzeyini artırmak suretiyle, oluşan bu hipereksitabl durumu geri çevirmeye çalıştığı speküle edilebilir. $\mathrm{Bu}$ konuda yapılacak prospektif çalışmalarla bu yorumların araştırılmasına ihtiyaç olduğu düşünülmektedir.

Literatür incelemesi sonucunda depresif ve bipolar duygu durum bozukluklarında serum magnezyum düzeyinde bir etkilenme olduğu gösterilmekle birlikte artış mı yoksa azalma $\mathrm{m} 1$ olduğu konusunda görüş birliğinin olmadığ 1 anlaşılmaktadır. Muhtemelen farklı sonuçlar üzerinde örneklem sayısındaki farklılıklar ve dâhil edilen hastaların özellikleri, uygulanan dişlama kriterleri etkili olmuş olabilir. Burada sunulan çalışmada depresif bozukluk hasta sayısı diğer bazı çalışmalarla kıyaslandığında daha fazla olmakla birlikte bipolar bozukluk hastası daha az sayıda kalmıştır. $\mathrm{Bu}$ da çalışmanın bir kısıtlılığını oluşturmaktadır. Verilerin retrospektif olarak elde edilmiş olması, hastalıkların süresi, şiddeti, başlangıç yaşı, geçirilen atak sayısı gibi bilgilerin kaydedilmemiş olması sebebiyle daha detaylı

\section{KAYNAKLAR}

1. Widmer J, Henrotte JG, Raffin Y, Mouthon D, Chollet D, Stépanian R, et al. Relationship between blood magnesium and psychomotor retardation in drug-free patients with major depression. Europeanpsychiatry. 1998;13 :90-97.

2. Ryan MF. The role of magnesium in clinical biochemistry: an overview. Annals of clinical biochemistry. 1991;28:19-26.

3. Serefko A, Szopa A, Poleszak E. Magnesium and depression. Magnesium research. 2016;29:112-19.

4. Szewczyk B, Poleszak E, Sowa-Kucma M, Siwek M, Dudek D, Ryszewska- analizler yapılamamış olması da çalışmanın bir başka kısıtlılığı olarak söylenebilir. Ayrıca çalışmadaki hastaların çoğunluğu psikotrop ilaç kullanan hastalardan oluşmaktaydı. Bu nedenle ilaç kullanımının etkisi dışlanamamıştır. Her ne kadar psikotrop ilaç kullanımının magnezyum düzeylerini etkilemediğini söyleyen çalışmalar olsa da $(21,23)$ ileride yapılacak çalışmalarda bu durumun göz önünde bulundurulması faydalı olacaktır. Çalışmanın kısıtlılıklarından bir tanesi de majör kronik hastalık tanısı olanlar çalışmaya dâhil edilmemiş olsa da diabetes mellitus, menopoz gibi magnezyum düzeyini etkileyen hastalıkların çalışmada dikkate alınmamasıdır.

Sonuç olarak bu çalışmada hem unipolar depresyon hem de bipolar duygu durum bozukluğu olan hastalarda kontrollere kiyasla daha yüksek serum magnezyum düzeyleri saptanmıştır. Bu sonuçlar serum magnezyum düzeylerinin bu hastalıklar için potansiyel bir biyomarker olabileceğine dair kanitlar sunsa da ileride yapılacak daha geniş serili ve diğer hastalık gruplarının da dâhil edildiği, kısitll1ıkların minimuma indirildiği prospektif çalışmalarla sonuçların desteklenmesinin literatüre olumlu katkısının olacağı düşünülmektedir.
Pokrasniewicz B, et al. Antidepressant activity of zinc and magnesium in view of the current hypotheses of antidepressant action. Pharmacological Reports. 2008;60: 588.

5. DeVinney R, Wang $\mathrm{HH}$, Mg2+ enhances high affinity [3H] 8-hydroxy-2(di-N-propylamino) tetralin binding and guanine nucleotide modulation of serotonin-1a receptors. Journal of Receptors and Signal Transduction. 1995;15:757-71.

6. Mark LP, Prost RW, Ulmer JL, Smith MM, Daniels DL, Strottmann JM, et al. Pictorial review of glutamate excitotoxicity: fundamental concepts for 
neuroimaging. American journal of neuroradiology. 2001;22:1813-1824.

7. Mayer ML, Westbrook GL, Guthrie PB. Voltage-dependent block by $\mathrm{Mg} 2+$ of NMDA responses in spinal cord neurones. Nature. 1984;309: 261.

8. Deb N, Lahon D, Chakravarty S. A study of serum magnesium and serum calcium in major depressive disorder. Open Journal of Psychiatry \& Allied Sciences. 2016;7.

9. Murck H. Ketamine, magnesium and major depression-From pharmacology to pathophysiology and back. Journal of psychiatric research. 2013;47: 955-65.

10. King DE, Mainous III AG, Geesey ME, Ellis T. Magnesium intake and serum Creactive protein levels in children. Magnesiumresearch. 2007;20: 32-36.

11. You HJ, Cho SE, Kang SG, Cho SJ, Na KS. Decreased serum magnesium levels in depression: a systematic review and meta-analysis. Nordic journal of psychiatry. 2018;72: 534-41.

12. Li B, Lv J, Wang W, Zhang D. Dietary magnesium and calcium intake and risk of depression in the general population: A meta-analysis. Australian \& New Zealand Journal of Psychiatry. 2017;51: 219-29.

13. Jacka FN, Overland S, Stewart R, Tell GS, Bjelland I, Mykletun A. Association between magnesium intake and depression and anxiety in communitydwelling adults: the Hordaland Health Study. Australian and New Zealand Journal of Psychiatry. 2009;43: 45-52.

14. Tarleton EK, Littenberg B, MacLean CD, Kennedy AG, Daley C. Role of magnesium supplementation in the treatment of depression: A randomized clinical trial. PLoS One. 2017;12(6): e0180067.

15. Eby GA, Eby KL. Rapid recovery from major depression using magnesium treatment. Medical hypotheses. 2006;67: 362-70.

16. Misztak P, Opoka W, Topór-Mądry R. The serum concentration of magnesium as a potential state marker in patients with diagnosis of bipolar disorder. Psychiatr Pol. 2015;49: 127787.
17. Styczeń K, Siwek M, Sowa-Kućma M, Dudek D, Reczyński W, Szewczyk B, et al. The serum magnesium concentration as a potential state marker in patients with unipolar affective disorder. Psychiatr $\quad$ Pol. 2015;49:126576.

18. Derom ML, Sayón-Orea C, MartínezOrtega JM, Martínez-González MA. Magnesium and depression: a systematic review. Nutritionalneuroscience. 2013; 16:191-206.

19. Cubała WJ, Landowski J, Szyszko M, Czarnowski W. Magnesium in drugnaïve patients with a short-duration, first episode of major depressive disorder: impact on psychopathological features. Magnesium research. 2013;26: 192-198.

20. Siwek M, Styczeń K, Sowa-Kućma M, Dudek D, Reczyński W, Szewczyk B, et al. The serum concentration of magnesium as a potential state marker in patients with diagnosis of bipolar disorder. Psychiatr Pol. 2015;49:127787.

21. Imada Y, Yoshioka SI, Ueda $T$, Katayama S, Kuno Y, Kawahara R. Relationships between serum magnesium levels and clinical background factors in patients with mood disorders. Psychiatry and clinical neurosciences. 2002;56: 509-14.

22. Morris ME. Brain and CSF magnesium concentrations during magnesium deficit in animals and humans: neurological symptoms. Magnesium Research. 1992;5: 303-13.

23. Naylor GJ, Fleming LW, Stewart WK, McNamee HB, Le Poidevin D. Plasma magnesium and calcium levels in depressive psychosis. The British Journal of Psychiatry. 1972;120:683-84. 